\title{
Análise das contratações públicas por intermédio de "carona" nas atas de registro de preços
}

\author{
Analysis of PUblic CONTRACTS THROUGH \\ "RIDE" IN THE PRICES REGISTERS \\ * Renata Carvalho Kobus
}

Resumo: O presente artigo versa sobre as contratações públicas realizadas mediante carona em ata de registro de preços de outro órgão público, havendo a ausência do devido procedimento licitatório. Primeiramente são tecidas breves considerações sobre o sistema de registro de preços, fundadas, basicamente, acerca das hipóteses de incidência deste procedimento e da maior eficácia que o mesmo proporciona à Administração Pública. Após, apresenta-se a conceituação do "carona" nas atas de registro de preços, assim como o modo pelo qual esta figura foi instituída em nosso sistema jurídico. Em seguida, aborda-se sobre a impossibilidade da utilização de registros de preços universais, principalmente em decorrência da existência de mercados geográficos e relevantes com características próprias. Na sequência, é realizado um estudo sobre as principais violações constitucionais e legais decorrentes da realização de carona nos procedimentos licitatórios para o registro de preços, sendo, posteriormente, apresentado os principais posicionamentos doutrinários e jurisprudenciais a respeito do assunto. Por fim, conclui-se pela impossibilidade de utilização da figura carona nas atas de registros de preços em razão da mesma, mesmo trazendo benefícios em determinados casos, ofender toda a sistemática jurídica brasileira atinente às contratações públicas.

Palavras-chave: Licitação; Registro de preços; Carona.

Abstract: This article focuses on public contracts realized by ride in another prices registers, without public bidding process. First of all, the article broach about the prices registers system focused on the efficiency that this system produced to Public Administration. Thereafter, is presented the concept of ride in the prices registers and the way that this figure was established in our legal system. After, is broached the impossibility of using universal prices registers in view of the existence of relevant markets and geographic markets with different characteristics. Subsequently, is realized a study about the constitutional and legal violations on account of the ride in the prices registers bidding process. At last, the conclusion shows the impossibility of the use of ride in the prices register because this figure offends our public contracts law and the Federal Constitution.

Keywords: Bidding Process; Prices Registers; Ride. 


\section{INTRODUÇÃO}

A Constituição Federal estabelece em seu artigo 37 os princípios que competem à Administração Pública obedecer, dentre os quais destaca-se o princípio da obrigatoriedade de licitação, o qual está estampado no artigo XXI do referido artigo.

Este princípio estabelece que os órgãos públicos devem realizar as suas contratações mediante licitação que assegure a igualdade de condições a todos os licitantes, ressalvados os casos especificados na legislação. $\mathrm{Ou}$ seja, a regra é de que toda a contratação pública seja precedida de procedimento licitatório a fim de se assegurar a maior concorrência possível entre os licitantes e, consequentemente, os melhores preços e serviços à Administração Pública.

O artigo 37, inciso XXI da Constituição Federal é regulamentado pela Lei $n^{\circ} 8.666 / 93$, a qual institui as normas para licitações e contratos administrativos, prevendo em seu inciso II do artigo 15 que, sempre que possível, as compras realizadas pela Administração Pública deverão ser efetuadas mediante registro de preços.

A grande discussão que atualmente este sistema de registros de preço vem gerando é relacionada à utilização deste sistema por outros órgãos públicos que não participaram do procedimento licitatório para a consecução deste registro, os chamados caronas.

O presente artigo visa realizar uma análise desta forma de contratação pública que, apesar de não possuir previsão legal, está sendo bastante utilizada pela Administração Pública.

A figura do carona seria uma afronta ao princípio da obrigatoriedade da licitação? Este aproveitamento de licitações já realizadas por outros entes públicos gera maior eficiência às contratações públicas? Haveria violação ao princípio constitucional da livre concorrência? Eis algumas questões que serão discutidas no presente trabalho sob a ótica do Direito Econômico e do ordenamento constitucional.

\section{BREVES CONSIDERAÇÕES SOBRE O SISTEMA DE REGISTRO DE PREÇOS}

O sistema de registro de preços é um procedimento administrativo que a Administração Pública deve adotar, sempre que for possível, para a realização 
de compras rotineiras de bens comuns ou mesmo para a obtenção de serviços possuindo previsão legal no artigo 15 da Lei no 8.666/1993 (Lei de Licitações).

Frise-se que a utilização do sistema de registro de preços visa justamente a diminuição dos custos transacionais, uma fez que na ausência deste procedimento, a Administração Pública teria que despender montantes significativos com a realização de vários procedimentos licitatórios para a aquisição de produtos e para a contratação de serviços freqüientes.

O sistema de registro de preços permite que a Administração Pública, ao invés de realizar diversos procedimentos licitatórios, realize apenas uma licitação, da qual se extrairá o registro de preço que poderá ser utilizado para as futuras necessidades de novas contratações, tendo o prazo de validade máximo de 12 meses.

Ou seja, o sistema de registro de preços proporciona uma maior eficiência à Administração Pública tendo em vista que o ente público pode realizar uma única licitação, ao invés de realizar diversas licitações para aquisições reiteradas e contínuas de produtos homogêneos e semelhantes, o que diminui significativamente os custos transacionais.

Ou seja, a contratação de forma rápida e simplificada propiciada pelo sistema de registro de preços diminui significativamente os custos a serem despendidos pela Administração Pública para a contratação de determinados produtos e/ou serviços, contribuindo para a uma maior eficácia da atuação da Administração Pública.

No que condiz aos benefícios do Sistema de Registro de Preços, Marçal Justen Filho (2009, p. 175) assevera que este é um dos meios mais fundamentais para a obtenção da eficiência nas contratações administrativas, uma vez que, através dele, o poder público não precisa multiplicar longos e complexos procedimentos, que resultam onerosos e inúteis ${ }^{1}$.

No âmbito federal, o sistema de registro de preços pode ser adotado nas seguintes circunstâncias: (i) se em razão das características do produto ou do serviço houver a necessidade de contratações freqüentes; (ii) quando for pertinente a compra de bens que possuam entregas parceladas; (iii) para a contratação remunerada de serviços em regime de tarefa ou que sejam por unidade de medida; iv) quando for pertinente a compra de bens ou a contratação

\footnotetext{
Nesse mesmo sentido, Fernanda Marinela afirma que este sistema propicia uma maior agilidade operacional, assim como uma maior eficiência, tendo em vista que é um modo mais rápido e eficaz que reduz custos, além de evitar a multiplicidade de licitações contínuas que se refiram a objetos semelhantes e homogêneos (MARINELA, 2012, p. 370).
} 
de serviços para o atendimento de programas do governo ou para mais de um órgão ou entidade da Administração Pública e; (v) quando, em razão da natureza do produto, for impossível a definição prévia do quantitativo a ser demandado pela Administração, conforme estabelece o artigo $3^{\circ}$ do Decreto $n^{\circ} 7892 / 2013$.

A seleção para o registro de preços é realizada por licitação na modalidade de concorrência, do tipo menor preço ${ }^{2}$, ou na modalidade de pregão (Lei $\mathrm{n}^{\circ}$ 10.520/2002), procedimentos estes que deverão ser precedidos por uma ampla pesquisa de mercado, devendo o registro ter o prazo máximo de 1 ano.

A existência do registro faz com que os preços de produtos e serviços sejam colocados à disposição da Administração Pública, não tendo esta o dever de firmar a contratação para a aquisição do bem/serviço licitado. Isto porque a existência do registro de preços não obriga a Administração Pública a firmar as contratações que deste registro poderão advir, podendo realizar as contratações necessárias mediante outros meios, desde que compatíveis com a Lei de Licitações ${ }^{3}$.

No entanto, diante dos custos transacionais decorrentes do sistema de registro de preços, assim como dos custos a serem gastos para a realização de novos procedimentos licitatórios, entende-se que caso a contratação pelo preço registrado se demonstre vantajosa, tendo-se como parâmetro a pesquisa de mercado, e não existam irregularidades no registro, compete à entidade promovedora deste registro a ele se submeter, sob pena de afronta ao princípio da eficiência ${ }^{4}$.

O parágrafo $3^{\circ}$ do artigo 15 da Lei de Licitações estabelece que o sistema de registro de preços será regulamentado por decreto, sendo que, no âmbito da Administração Pública Federal, esta regulamentação foi realizada pelo Decreto Federal no 7892/2013.

\footnotetext{
${ }^{2}$ Frise-se que o parágrafo $1^{\circ}$ do artigo $7^{\circ}$ do Decreto $n^{\circ} 7892 / 2013$ possibilita que no procedimento licitatório para o sistema de registro de preço seja utilizado excepcionalmente o julgamento por melhor técnica e preço, mediante despacho fundamentado.

3 É a redação do $\S 4^{\circ}$ do artigo 15 da Lei de Licitações: "A existência de preços registrados não obriga a Administração a firmar as contratações que deles poderão advir, ficando-lhe facultada a utilização de outros meios, respeitada a legislação relativa às licitações, sendo assegurado ao beneficiário do registro preferência em igualdade de condições".

${ }^{4}$ Nesse diapasão, destaca-se o entendimento de Diógenes Gasparini: "Uma vez registrados os preços, estes valores valerão para todas as compras futuras que forem do interesse da entidade promotora do registro, restando seu fornecedor obrigado à provisão do bem quando e como solicitado. De sorte que não está obrigado a observar o valor registrado em relação à entidade que não tenha sido a promotora desse registro, salvo se o edital regular esta obrigação. Embora o registro obrigue, em princípio, a entidade que o promoveu, não está obrigada a observá-lo quando a aquisição revelar-se desvantajosa ou o registro ressentir-se de irregularidades. Fora essas hipóteses, cremos que, promovido o registro, a ele se submete a entidade que o promoveu, sob pena de incompatibilidade desses comportamentos" (GASPARINI, 2010, p. 558).
} 
Insta salientar que o decreto regulamentador deve atender as peculiaridades regionais, o que faz com que a sua aplicação seja limitada ao ente federativo que o criou, além de não poder criar novos direitos, sob pena de caracterizar-se como ilegal.

A respeito deste assunto Marçal Justen Filho (2009, p. 186) assevera que a regulamentação do registro de preços prevista no artigo 15 da Lei de Licitações deve ser realizada no âmbito de cada unidade federativa, o que não afasta a autoaplicabilidade deste dispositivo.

Isto porque a disciplina constante na Lei de Licitações é plenamente suficiente para a instituição do registro de preços, não havendo a necessidade de veiculação de outras normas regulamentares. Inclusive, ressalta-se que diversas das inovações que são trazidas pela regulamentação são eivadas de ilegalidade em razão de ultrapassarem os limites estabelecidos legislativamente.

Desta forma, verifica-se que o decreto regulamentador apenas possuirá eficácia no âmbito da entidade federativa que o criou ${ }^{5}$ e, caso apresente inovações não estabelecidas em lei, estará em desconformidade com os limites legais.

Insta salientar que mesmo que o sistema de registro de preços apresente significativos benefícios à Administração Pública, a sua utilização, deve, necessariamente, observar às limitações existentes, sob pena de ofensa aos princípios constitucionais e à segurança de nosso ordenamento jurídico.

Ademais, ressalta-se que a utilização indevida deste sistema, por exemplo, através da realização de carona, pode até mesmo acarretar em prejuízos significativos à Administração Pública, além de resultar em ofensa ao princípio constitucional da livre concorrência, como se passa a demonstrar.

\section{DA REALIZAÇÃO DE CARONA EM PROCEDIMENTO LICITATÓRIO PARA O REGISTRO DE PREÇOS}

A carona em registro de preços é realizada quando um ente ou órgão que não participou do procedimento licitatório se aproveita do registro de preços de outro ente/órgão, se eximindo da realização do adequado

\footnotetext{
5 Nesse mesmo sentido, destaca-se o seguinte entendimento doutrinário: “A Administração Pública federal direta, autárquica e fundacional, os fundos especiais, as empresas públicas, as sociedades de economia mista e demais entidades controladas direta ou indiretamente pela União obedecerão ao disposto no Decreto federal n. 3.931/2001, quando desejarem contratar serviços ou adquirir bens. Essa legislação regulamentar não se aplica aos demais entes da Federação, cabendo-lhe editar a própria legislação, ou seja, lei e regulamento do sistema de registros de preços. Embora seja assim, o que se tem visto é a edição, por essas pessoas políticas, apenas do decreto regulamentar" (GASPARINI, 2012, p. 557).
} 
procedimento licitatório, violando, de tal forma, os ditames insculpidos na Lei ${ }^{\circ}$ 8.666/1993.

Ou seja, determinado ente/órgão público se aproveita de um procedimento licitatório realizado por outra pessoa, ou seja, de uma licitação que nem chegou a participar, não sendo parte legítima para exigir da empresa licitada que preste seus serviços nas condições pactuadas com a licitante com qualquer outro ente/ órgão da Administração Pública.

No âmbito federal a possibilidade de carona nos registros de preços está prevista no artigo 22 do Decreto $n^{\circ} 7892 / 2013^{6}$, o qual estabelece que desde que justificada a vantagem, a "ata de registro de preços, durante a sua vigência, poderá ser utilizada por qualquer órgão ou entidade da Administração Pública federal que não tenha participado do certame licitatório, mediante anuência do órgão gerenciador".

Como limitação a adesão da ata de registro de preço por órgão não participante do procedimento licitatório, o parágrafo $3^{\circ}$ do dispositivo legal acima mencionado estabelece que a contratação não poderá ser superior a "cem por cento dos quantitativos dos itens do instrumento convocatório e registrados na ata de registro de preços para o órgão gerenciador e órgãos participantes".

Tendo em vista que o carona ${ }^{7}$ é uma figura que está fora da relação administrativa que realizou a licitação para o registro de preços, não pode dela se utilizar, eximindo-se da realização do devido procedimento licitatório.

Desta forma, verifica-se a existência de diversos contratos que giram em torno do sistema de registro de preços. Tais contratos possuem como nexo de causalidade a utilização da ata do registro de preços e apresentam todos uma finalidade comum, qual seja, a aquisição do mesmo produto ou serviço.

Ademais, todos estes contratos apresentam como contratado o mesmo agente, aquele vencedor do procedimento licitatório que originou o registro de preços. Diante desta relação existente entre tais contratos pode-se até mesmo afirmar que estamos diante de uma rede contratual.

\footnotetext{
${ }^{6}$ Destaca-se o entendimento de Susan Rose-Ackerman acerca da existência de grupos de barganha para a promulgação de leis, ao tratar a análise da legislação pela Public Choice: "Realismo também exige que se reconheça que barganhas de grupos de interesses não podem ser evitadas em uma democracia representativa. Elas são o custo das regras de votação que não sejam extremamente tendenciosas para a manutenção do status quo. Na medida em que a produção de riqueza por mercados privados não esteja de acordo com algum status normativo específico, deve-se aceitar o fato de que as escolhas políticas ajudarão alguns e prejudicarão outros, e as pessoas procurarão ficar ao lado do vencedor" (ROSE-ACKERMAN In MATTOS, 2004, p. 241).

7 O inciso V do artigo $2^{\circ}$ do Decreto $n^{\circ} 7892 / 2013$ conceitua a figura do carona como "órgão ou entidade da administração pública que, não tendo participado dos procedimentos iniciais da licitação, atendidos os requisitos desta norma, faz adesão à ata de registro de preços".
}

REVISTA DO DIREITO PÚBLICO, Londrina, v.10, n.1, p.211-228, jan./abr.2015 
Rodrigo Xavier Leonardo (2003, p. 145) conceitua a rede contratual como "um sistema de contratos constituído em razão de uma finalidade operacional comum entre os diversos agentes econômicos interessados em potencializar benefícios e minimizar riscos".

No caso da carona em registro de preços, a finalidade operacional comum seria a necessidade de aquisição do mesmo produto ou serviço, o que se dá através da utilização da ata de registro de preços de um outro órgão público. A justificativa que é dada a este procedimento gira em torno da potencialização de benefícios e da minimização de riscos.

Contudo, a potencial existência de benefícios e a suposta diminuição dos riscos não é suficiente para que a Administração Pública tenha a permissão de desenvolver determinada conduta. Os efeitos da realização de carona nas atas de registro de preços podem tornar a contratação mais eficiente, assim como podem torná-la bem menos vantajosas ao Poder Público, o que ocorre principalmente em decorrência da restrição da concorrência.

Ademais, mesmo que esta contratação fundada na carona em ata de registro potencialmente traga benefícios, a Administração Pública não pode realizar o que não está previsto lei, sob pena de ofensa ao princípio da legalidade, assim como a ofensa de diversos outros princípios e normas constitucionais e infralegais.

Importante salientar que o órgão público não possui a discricionariedade realizar o devido procedimento licitatório ou de contratar determinada empresa que possui o registro de preço para outro órgão público. Deve, necessariamente, realizar o devido procedimento licitatório, sob pena de ofensa ao princípio da obrigatoriedade de licitação e os demais princípios decorrentes desta violação.

\subsection{Da impossibilidade de utilização universal dos registros de preços}

As condições do produto e dos serviços podem variar significativamente de uma região para outra, não podendo haver uma utilização nacional de determinado registro de preços.

A existência de mercados relevantes e mercados geográficos distintos fazem com que os produtos e serviços sofram, muitas vezes, alterações significativas em seu preço, sendo inviável o "tabelamento" de preços em âmbito 
nacional ou até mesmo estadual, inviabilidade esta que se agrava conforme o grau de variação das condições específicas de cada produto ou serviço.

A título exemplificativo, um produto que somente é produzido no norte do país certamente será vendido mais caro na região sul, tendo em vista a existência dos custos de transação com, por exemplo, o transporte desta mercadoria até o outro lado país.

A existência de um procedimento licitatório que visasse o registro de preços em âmbito nacional certamente excluiria as empresas de pequeno e médio porte do certame, diminuindo, de tal forma, a competitividade.

Ao diminuir a concorrência entre os agentes econômicos tanto a existência de um registro de preços nacional quanto a existência da carona em tais registros propiciam a concentração de poder econômico em determinada empresa, o que apresenta-se como um sério obstáculo ao desenvolvimento e à expansão de novos agentes econômicos no mercado.

Visando superar esta restrição de empresas contratantes com a Administração Pública, o Decreto n ${ }^{\circ} 7892 / 2013$, além de possuir a limitação quantitativa para a realização da carona, prevê que é vedado aos entes e órgãos da Administração Pública federal a adesão a registros de preços que tenham sido realizados por entidade ou órgão das demais esferas de poder (estadual, distrital e municipal).

\subsection{Das violações constitucionais e legais decorrentes da realização de carona nos procedimentos licitatórios para o registro de preços}

Primeiramente, cumpre salientar que a realização de carona em licitação por parte dos órgãos públicos para se eximirem da realização de procedimento licitatório não possui previsão legal, o que acarreta na violação do princípio da legalidade.

Se à Administração Pública somente é permitido fazer o que está descrito em lei, não pode esta se beneficiar de uma condição que a lei não a autoriza e deixar de realizar o procedimento licitatório que é seu dever legal, previsto na Lei $n^{\circ} 8.666 / 1993$. Desta forma, o carona não possui legitimidade para se aproveitar de um procedimento licitatório realizado por outrem, em razão de não haver em lei a previsão desta conduta.

O princípio da legalidade é violado em razão da figura do carona não possuir previsão legal. Possui previsão somente nos decretos regulamentares, os quais não possuem o condão de criar direitos. Assim sendo, verifica-se 
que tais decretos indevidamente criam direitos, o que somente pode ser feito mediante lei.

Destaca-se que o Prejulgado n ${ }^{\circ} 1895$ do Tribunal de Contas do Estado de Santa Catarina ${ }^{8}$ estabelece que os decretos e as resoluções regulamentadoras não possuem o condão de dispor para além da Lei n ${ }^{\circ}$ 8.666/1993 e/ou de contrariar os dispositivos constitucionais ${ }^{9}$.

Com relação a criação da figura do carona por decreto, cumpre ressaltar que esta via não é a correta, pois, enquanto a lei possui natureza jurídica de ato normativo primário, por poder criar novo direito, o decreto regulamentar é ato normativo secundário, por apenas possuir o condão de estabelecer normas que viabilizam a melhor forma de execução da lei.

Acerca desta impossibilidade do decreto criar novos direitos, Maria Sylvia Zanella Di Pietro afirma que enquanto a lei é ato normativo originário por criar direito novo originário de órgão público dotado de competência constitucional, "o decreto regulamentar é ato normativo derivado (porque não cria direito novo, mas apenas estabelece normas que permitem explicar a forma de execução da lei)" (DI PIETRO, 2011, p. 235).

Salienta-se que o Egrégio Superior Tribunal de Justiça também possui o entendimento consolidado de que "o decreto regulamentar não pode ir além do disposto na lei a que se refere" 10 . Assim sendo, demonstra-se evidente que a utilização de carona em licitação permitida por decreto regulamentador fere ao princípio da legalidade, uma vez que o regulamento não é meio de criar direito, mas de apenas explicitar e detalhar a competência já criada mediante lei.

Pode-se até mesmo mencionar que a contratação firmada entre a empresa vencedora da licitação para o registro de preços e outros órgãos públicos que não fizeram parte deste procedimento licitatório, viola o princípio da legalidade também em decorrência da ofensa ao princípio da vinculação ao edital.

8 TCE/SC, Decisão no 2392/07, Processo CON 07/00001662, Relator Conselheiro Wilson Rogério Wan-Dall, julgado em 06.08.07, publicado em 23.08.07.

9 É a redação do Prejulgado no 1895 do TCE/SC: "PREJULGADO 1895 - 1. O Sistema de Registro de Preços, previsto no art. 15 da Lei (federal) n. 8.666/93, é uma ferramenta gerencial que permite ao Administrador Público adquirir de acordo com as necessidades do órgão ou da entidade licitante, mas os decretos e as resoluções regulamentadoras não podem dispor além da Lei das Licitações ou contrariar os princípios constitucionais. 2. Por se considerar que o sistema de "carona", instituído no art. $8^{\circ}$ do Decreto (federal) n. 3.931/2001, fere o princípio da legalidade, não devem os jurisdicionados deste Tribunal utilizar as atas de registro de preços de órgãos ou entidades da esfera municipal, estadual ou federal para contratar com particulares, ou permitir a utilização de suas atas por outros órgãos ou entidades de qualquer esfera, excetuada a situação contemplada na Lei (federal) n. 10.191/2001" (TCE/SC, Decisão n 2392/07, Processo 07/00001662, Relator Conselheiro Wilson Rogério Wan-Dall, julgado em 06.08.07, publicado em 23.08.07).

${ }^{10}$ STJ, REsp 433.829/SP, Rel. Ministro Francisco Peçanha Martins, julgado em 20.09.2005, publicado em 24.10.2005. 
Esta violação ao princípio da vinculação ao edital decorre do fato da contratação com os órgãos públicos que pegam carona em registro de preços não estar prevista no edital de licitação. A possibilidade da empresa vencedora do certame para registro de preços poder firmar contrato, sem ter que participar novamente de qualquer outro procedimento licitatório pode alterar significativamente o interesse das potenciais participantes do certame.

Empresas que até então não possuíam interesse em participar da licitação podem passar a tê-lo, em decorrência de saberem que poderiam firmar diversas outras contratações sem licitação com outros órgãos públicos.

Esta perspectiva pode até mesmo propiciar uma maior concorrência no procedimento licitatório, o que certamente acarretaria em benefícios à Administração Pública.

Contudo, esta sistemática apenas seria legítima caso houvesse a devida previsão legal e se, desde o momento da realização do edital de licitação, os órgãos públicos que possuíssem a necessidade de aquisição dos mesmos produtos ou serviços participassem do procedimento licitatório.

Ademais, para que não houvesse afronta aos princípios aplicáveis à Administração Pública, far-se-ia necessário que no edital da licitação houvesse a devida especificação do objeto, assim como a informação de quais os órgãos públicos que poderão se utilizar da ata de registro de preços, além, por óbvio, do cumprimento dos demais requisitos previstos em lei.

A ausência de tais informações proporciona uma condição privilegiada ao agente vencedor do procedimento licitatório, o qual poderá firmar contratos com diversos outros órgãos públicos, sem a necessidade de vencer outros procedimentos licitatórios.

Assim sendo, ao invés de novas licitações serem instauradas, propiciando a igualdade de condições entre os interessados em participar do certame, o que ocorre é a contratação privilegiada e arbitrária de uma empresa que foi vencedora de um outro procedimento licitatório, violando, de forma, o princípio da isonomia.

Outro grande problema encontrado na realização da carona nos registros de preços é relativa a potencial existência de lobby da empresa vencedora da licitação para que diversos outros órgãos públicos firmem consigo contrato, ao invés de realizarem procedimento licitatório.

Em relação a violação à concorrência advinda da existência de tais lobbies, Carlos Ari Sundfeld (2012, p. 63) afirma que no campo das aquisições 
públicas a aplicação do princípio da concorrência, apesar de existir e ser profunda, vem sendo constantemente modulada em razão da existência lobbies.

Infelizmente estes lobbies advindos dos agentes econômicos visam apenas a execução de seus interesses capitalistas, os quais, na grande maioria das vezes, importam na afronta das normas éticas e legais, apenas levandose em consideração a busca por lucros cada vez maiores.

A utilização dos efeitos de outros procedimentos licitatórios também pode se apresentar como bastante prejudicial à Administração Pública, pois acarreta na violação do princípio da economicidade.

Isto porque, os licitantes formulam as suas propostas com base nos quantitativos estabelecidos no edital convocatório. Assim sendo, quanto maior for o quantitativo a ser licitado, menor será o preço atribuído ao produto ou ao serviço, pois esta é a lógica da economia em escala (NUSDEO, 2010, p. 152).

No caso de carona nas atas de registros de preços, esta economia em escala é desconsiderada tendo em vista que no edital convocatório apenas consta o quantitativo máximo pelo qual o órgão licitante poderá se utilizar.

Como no edital convocatório não consta o quantitativo que os caronas irão adquirir da empresa que possui o registro de preços, as empresas participantes da licitação estipulam o preço de suas propostas somente em conformidade com a quantidade descrita em edital, desconsiderando os quantitativos que podem ser adquiridos mediante a carona no sistema.

\subsection{Das divergências existentes entre os posicionamentos acerca da figura do carona}

Ressalta-se que o entendimento acerca da legalidade ou não do "carona" não é unânime, havendo divergência tanto doutrinária quanto jurisprudencial a seu respeito.

Marçal Justen Filho (2009, p. 198) afirma que esta "solução desbordou os limites da lei e produziu resultado teratológico, especialmente porque propicia contratações ilimitadas com base em uma mesma e única licitação".

Em razão desta restrição à realização dos procedimentos licitatórios, este doutrinador conclui que a figura do carona "é inquestionavelmente ilegal e eivada de uma série de vícios. Mas isso não impediu que fosse praticada no âmbito do próprio Tribunal de Contas da União" (JUSTEN FILHO, 2009, p. 198). 
A título exemplificativo, de modo divergente ao posicionamento adotado por Marçal Justen Filho, o doutrinador Regis Fernandes de Oliveira (2013, p. 06) entende que a figura do carona não é inconstitucional e nem ilegal, sendo que este procedimento pode diminuir o custo de diversas obras e serviços, assim como facilitar as contratações.

No entanto, mesmo possuindo o entendimento de que a figura do carona propicia benefícios, Regis Fernandes de Oliveira (2013, p. 06) adverte que a realização de carona em procedimentos licitatórios não pode ser considerada como um princípio absoluto, de forma a servir para toda contratação pública, uma vez que, como diria Aristóteles, a virtude está no meio ${ }^{11}$.

O Tribunal de Contas da União firmou o entendimento no Acórdão ${ }^{\circ}$ $1.233 / 2012^{12}$ no sentido de que é possível a realização da "carona", sendo que, devido a necessidade de observância do princípio da vinculação ao edital, devese "gerenciar a ata de forma que a soma dos quantitativos contratados em todos os contratos derivados da ata não supere o quantitativo máximo previsto no edital".

Contrariamente ao posicionamento adotado pelo Tribunal de Contas da União, destaca-se o entendimento do Tribunal de Contas do Estado do Paraná ${ }^{13}$ de que a adesão à ata de registro de preços de outros órgãos públicos

\footnotetext{
${ }^{11}$ Acerca da violação de princípios decorrente da licitação carona, destaca-se o seguinte entendimento: "O 'carona', no mínimo, expõe os princípios da moralidade e da impessoalidade a risco excessivo e despropositado, abrindo as portas da Administração a todo tipo de 'lobby', tráfico de influências e favorecimento pessoal (...). O representante legal de dada entidade é quem decide, praticamente de forma livre, se adere à ata de registro de preços de outra entidade ou não e, com isso, se beneficia ou não o fornecedor que assinou a aludida ata de registro de preços. E, em meio a esse processo decisório, há um grande risco de o representante da entidade aceitar alguma espécie de agrado para beneficiar o fornecedor e optar pelo 'carona', o que, se ocorrer, importa agravo ao princípio da moralidade e, junto com ele, ao da impessoalidade" (GUIMARÃES; NIEBUHR, 2008, p. 123-124).

${ }^{12}$ TCU, AC 1233/2012, Processo $n^{\circ}$ 011.772/2010-7, Relator Conselheiro Aroldo Cedraz, julgado em 23.05.2012, publicado em 23.05.2012.

${ }^{13}$ Destaca-se o seguinte trecho do Acórdão no 984/2011 do TCE/PR: "Para aquela outra entidade, que vai aproveitar esse edital de licitação, os fornecedores que teriam interesse em participar da licitação dessa outra entidade que está pegando carona e não participaram, evidentemente, parece-me que houve uma infração ao princípio da igualdade. Não se está dando a eles a oportunidade de participar da licitação. Então, parece-me que, dada a dimensão continental de um país como o nosso, o simples fato de haver a divulgação nacional parece-me que não supre essa lacuna. Porque evidente que nem todo mundo tem tempo de ficar o tempo inteiro verificando editais licitatórios de todas as entidades da federação, incluindo os estados e todos os municípios. Então me parece aí uma violação grave ao princípio da igualdade. Eu vejo ainda uma violação ao princípio da economicidade, e não sou eu quem vê, na verdade, são os mesmos autores que eu já citei, na medida em que nós estamos transferindo, o poder público, está transferindo para a iniciativa privada o ganho que ele poderia ter decorrente da economia de escala. Então, uma empresa que fixou o preço para cem, ela vai ter a possibilidade de vender pelo mesmo preço para mil itens. Ao passo que, o poder público, sabendo que seria o mil e não cem, poderia ter feito uma
} 
não deve ser realizada em razão desta conduta apresentar, em síntese, os seguintes óbices: i) ofensa ao princípio da legalidade; ii) violação ao princípio da habilitação; iii) infração ao limite legal e ampliação dos limites quantitativos; iv) ofensa ao princípio da república; v) ofensa ao princípio da isonomia; vi) indução à corrupção e; vii) padronização de objetos, conforme estampado no Acórdão n ${ }^{\circ} 984 / 2011^{14}$.

Nesse mesmo sentido, de que a licitação carona viola aos princípios basilares da Administração Pública, é o posicionamento do Tribunal de Contas do Estado de São Paulo, o qual também preza pela inviabilidade da utilização do carona.

\section{CONSIDERAÇÕES FINAIS}

O sistema de registro de preços, previsto no artigo 15 da Lei de Licitações e no Decreto $n^{\circ} 7892 / 2013$ (âmbito federal) é um instrumento que tornou as contratações públicas de produtos e serviços homogêneos e semelhantes muito mais eficiente.

Isto porque este sistema diminui significativamente os custos transacionais tendo em vista que, ao invés da necessidade de realização de diversas licitações para a aquisição reiterada e contínua de produtos e serviços, o órgão público pode realizar uma única licitação que poderá ter seus efeitos válidos por até 12 meses.

Contudo, apesar deste sistema apresentar significativas vantagens à Administração Pública, deve ser usado com cautela, sempre levando em consideração a prevalência do interesse público, assim como a devida observância aos princípios e regras constitucionais e legais.

\footnotetext{
proposta de preço bem mais vantajosa. Então me parece que há uma violação sim ao princípio da economicidade. E, o mais grave de todos, me parece o último aspecto que o Dr. Heinz materializou em exemplos concretos, mas que eu vejo como a discricionariedade que é dada ao administrador, aquela entidade que vai, que pretende aderir, de poder escolher se adere ou não à licitação. Parece-me quer toda concepção da licitação, e isso está no artigo terceiro da licitação, é baseada em princípios da objetividade, em princípios da impessoalidade, em princípios da moralidade, princípios da legalidade, que me parece que não se coadunam com essa possibilidade dada ao gestor de poder ou não aderir a uma determinada ata. Parece-me que há uma carta em branco ao gestor para ele tomar uma atitude ou outra e, a lei de licitações e os princípios das contratações de direito público parece-me que não permitem esse alargamento dessa possibilidade" (TCE/PR, AC 984/ 2011, Processo $n^{\circ}$ 449127/2008, Relator Conselheiro Sérgio Ricardo Valadares Fonseca, julgado em 09.06.2011, publicado em 23.12.2011).

${ }^{14}$ TCE/PR, AC 984/2011, Processo ${ }^{\circ}$ 449127/2008, Relator Conselheiro Sérgio Ricardo Valadares Fonseca, julgado em 09.06.2011, publicado em 23.12.2011).
} 
No entanto, a atual realidade não é bem esta. Isto porque os órgãos públicos passaram a ver o sistema de registro de preços como um meio hábil para burlar o procedimento licitatório, o que ocorre mediante a "carona" de um órgão público em ata de registro de preços de um outro ente público.

Esta conduta de carona nas atas de registros de preços consiste na realização de contrato público sem ser precedido de procedimento licitatório. Frise-se que o ente contratado pelo carona venceu um procedimento licitatório que foi promovido por um outro ente público. Ou seja, as partes contratuais não são condizentes, em sua integralidade, com o órgão licitante e com a empresa vencedora do procedimento licitatório.

Desta forma, este aproveitamento de um agente que venceu determinado procedimento licitatório por um órgão público que não participou do certame licitatório, restringe a possibilidade de outras empresas terem a oportunidade de serem contratadas pela Administração Pública que se utiliza da carona de atas de registro de preço.

Assim sendo, além da violação à obrigatoriedade de realização de licitação por parte dos órgãos públicos, verifica-se que o sistema de carona em atas de registro de preços acaba por beneficiar discricionariamente o agente que venceu outro procedimento licitatório, o que enseja a quebra da isonomia entre os interessados na contratação com o órgão público que realizou a carona.

Ademais, esta conduta viola a necessidade de vinculação ao edital licitatório, em razão deste não prever todos os órgãos que poderão contratar com o vencedor do certame. Consequentemente também há ofensa ao princípio da igualdade entre os participantes, tendo em vista que a abertura do leque para o agente privado contratar com outros órgãos públicos, sem necessidade de vencer novo procedimento licitatório, é uma circunstância bastante apta a influir não somente no interesse dos agentes em participarem do certame, mas também nos valores a serem propostos pelos mesmos.

Além disso, a realização deste sistema de carona pelos órgãos públicos na ausência de permissão legal, enseja na violação do princípio da legalidade. Frise-se que a previsão em decreto não é suficiente para regularizar esta situação em razão deste meio não ser hábil a criar direitos, por ser ato normativo secundário e não primário.

Diante do exposto, verifica-se que a figura do carona nas atas de registros de preços somente pode ser aceita caso haja a devida previsão 
legal permitindo esta conduta e deste que o edital de licitação informe os órgãos públicos que poderão aderir a ata, assim como o quantitativo máximo a ser objeto do contrato, o qual também deve considerar a quantia que poderá ser contratada pelos caronas.

Desta forma, as contratações discricionárias que privilegiam injustificadamente certos agentes cessarão, uma vez que a figura do carona estará adequada ao nosso ordenamento jurídico, gerando os benefícios decorrentes da diminuição dos custos transacionais sem que haja a violação aos princípios supracitados.

Assim sendo, esta figura do carona que hoje se apresenta como um problema, caso seja adequada às normas e princípios constitucionais e legais, passará a ser um instrumento propiciador de uma maior eficiência nas contratações públicas, ao diminuir a sua complexidade, reduzir os custos de transação e proporcionar uma maior agilidade na sua consecução.

\section{REFERÊNCIAS}

CATERMOL, Fabrício. Inovações e Contestabilidade: algumas considerações sobre eficiência econômica. Disponível em: http:// www.bndes.gov.br/SiteBNDES/export/sites/default/bndes_pt/Galerias/ Arquivos/conhecimento/revista/rev2206.pdf, acesso em 05/09/2011.

CARVALHO, Orlando de. Contrato Administrativo e Acto Jurídico Público. In: Escritos: páginas de Direito. v. I. Coimbra: Almedina, 1998.

COASE, Ronald H. The Nature of the Firm. Disponível em: http:// www.sonoma.edu/users/e/eyle r/426/coase1.pdf, acesso em 08/07/2011.

COMPARTO, Fabio Konder. Regime constitucional do regime de preços. Revista de Direito Público, v.24, n.9, jan/mar, 1991.

DI PIETRO, Maria Sylvia Zanella. Direito Administrativo. 24a edição. São Paulo: Atlas, 2011.

ELZINGA, Kenneth G. The goals of antitrust: other than competition and efficiency, what else counts?. University of Pennsylvania Law 
Rewiew. Disponível em: www.jstor.org/stable/3311439, acesso em 15.02.2014.

ENTRERRÍA, Eduardo García de; FERNÁNDEZ, Tomás-Ramón. Curso de Derecho Administrativo. v. II. 9ª Ed. Madri: Thomson/Civitas, 2004. FORGIONI, Paula A. Os fundamentos do Antitruste. $4^{\mathrm{a}}$ edição. São Paulo: Revista dos Tribunais, 2010.

GALESKI JUNIOR, Irineu; RIBEIRO, Marcia Carla Pereira (coords.). Teoria Geral dos Contratos: contratos empresariais e análise econômica. Rio de Janeiro: Elsevier, 2009.

GASPARINI, Diógenes. Direito Administrativo. $17^{a}$ edição. São Paulo: Editora Saraiva, 2012.

GUIMARÃES, Edgar; NIEBUHR, Joel de Menezes. Registro de preços: aspectos práticos e jurídicos. Belo Horizonte: Editora Fórum, 2008.

GRAU, Eros Roberto. A ordem econômica na Constituição de 1988. $14^{\circ}$ edição. São Paulo: Malheiros, 2010.

HOVEMKAMP, Herbert. Distributive Justice and Antitrust Law.

Disponível em: http://heinonline.org/HOL/

LandingPage?collection=journals\&handle=hein.journals/

gwlr51\&div=9\&id=\&page $=$, acesso em 15/02/2014.

JUSTEN FILHO, Marçal. Comentários à Lei de Licitações e Contratos Administrativos. 13 $3^{a}$ edição. São Paulo: Dialética, 2009.

KLEIN, Vinícius; RIBEIRO, Marcia Carla Pereira (coords.). O que é Análise Econômica do Direito: uma introdução. Belo Horizonte: Editora Fórum, 2011.

LEONARDO, Rodrigo Xavier. Redes Contratuais no mercado habitacional. São Paulo: Editora RT, 2003. 
MARINELA, Fernanda. Direito Administrativo. $6^{a}$ edição. Niterói: Impetus, 2012.

MELLO, Celso Antônio Bandeira de. Curso de Direito Administrativo. 29ª edição. São Paulo: Malheiros, 2012.

\section{NUSDEO, Fabio. Curso de Economia: introdução ao direito} econômico. $6^{\text {a }}$ Ed. São Paulo: Editora Revista dos Tribunais, 2010.

OLIVEIRA, Regis Fernandes de. Análise evolutiva das licitações no Brasil. São Paulo, Revista dos Tribunais Online, v.01, jul. 2013.

RAGAZZO, Carlos Emmanuel Joppert. Notas introdutórias sobre o princípio da livre concorrência. Revista de Direito da Concorrência, $n^{\circ} 6$, abr/jun, 2005.

ROSE-ACKERMAN, Susan. Análise Econômica progressista do Direito - e o novo direito administrativo. Trad. Marina Mota Prado. In: MATTOS, Paulo (coord.). Regulação Econômica e Democracia: o debate norteamericano. São Paulo: CEBRAP, 2004.

SALOMÃO FILHO, Calixto. Regulação da atividade econômica. $2^{\mathrm{a}}$ Ed. São Paulo: Malheiros, 2008.

STJ, REsp 433.829/SP, Rel. Ministro Francisco Peçanha Martins, julgado em 20.09.2005, publicado em 24.10.2005.

SUNDFELD, Carlos Ari. Contratações Públicas e o princípio da concorrência. Belo Horizonte, Revista de Contratos Públicos, ano 1, n. 1, p. 55-79, mar./ago 2012.

TCE/PR, AC 984/2011, Processo n ${ }^{\circ}$ 449127/2008, Relator Conselheiro Sérgio Ricardo Valadares Fonseca, julgado em 09.06.2011, publicado em 23.12.2011.

TCE/SC, Decisão n 2392/07, Processo CON 07/00001662, Relator Conselheiro Wilson Rogério Wan-Dall, julgado em 06.08.07, publicado em 23.08.07. 
TCU, AC 1233/2012, Processo $n^{\circ}$ 011.772/2010-7, Relator Conselheiro Aroldo Cedraz, julgado em 23.05.2012, publicado em 23.05.2012.

Artigo recebido em: 08/04/2014 Aprovado para publicação em: 29/04/2015

Como citar: KOBUS, Renata Carvalho. Análise das contratações públicas por intermédio de "carona" nas atas de registro de preços. Revista do Direito Público. Londrina, v.10, n.1, p.211-228, jan./abr.2015. DOI: 10.5433/ 1980-511X.2015v10n1p211. 